\title{
Stosowanie przepisów Kodeksu postępowania administracyjnego o milczącym załatwieniu sprawy
}

\section{Wprowadzenie}

Wraz z wejściem w życie Ustawy z dnia 7 kwietnia 2017 r. o zmianie ustawy - Kodeks postępowania administracyjnego oraz niektórych innych ustaw ${ }^{1}$ nastąpiło wprowadzenie do Kodeksu postępowania administracyjnego ${ }^{2}$ instytucji milczącego załatwienia sprawy. Idea, która legła u podstaw objęcia przedmiotem regulacji Kodeksu wyartykułowanej instytucji prawnej, było zapewnienie odpowiedniej efektywności procesowi stosowania prawa na drodze administracyjnej, zmniejszenie w sposób odczuwalny społecznych kosztów uruchamiania procedury oraz maksymalne odformalizowanie działań podejmowanych w trybie urzędowym $^{3}$. U źródeł koncepcji tkwiła również, a może przede wszystkim, potrzeba uporządkowania i kompleksowego unormowania materii indywidualnych spraw administracyjnych załatwianych milcząco, które dotąd funkcjonowały w systemie materialnego prawa administracyjnego w sposób rozproszony, ze zróżnicowaną specyfiką rozwiązań formalnoprawnych ${ }^{4}$. Miarą tak założonego procesu kodyfikacyjnego miało

${ }^{1}$ Dz.U. poz. 935.

${ }^{2}$ Ustawa z dnia 14 VI 1960 r. Kodeks postępowania administracyjnego (tekst jedn. Dz.U. 2018, poz. 2096), dalej „k.p.a.” lub „Kodeks”.

${ }^{3}$ Por. Z. Kmieciak, Słowo wstępne, w: Raport Zespołu Eksperckiego z Prac w latach 2012 2016. Reforma prawa o postepowaniu administracyjnym, pod red. Z. Kmieciaka, Warszawa 2017, s. 11 i n.

${ }^{4} \mathrm{Na}$ problem ten zwraca uwagę m.in. W. Gurba, Bezczynność i przewlekłość postępowania. Milczace załatwienie spraw (art. 14 §3, art. 36-38, art. 104a-104c), w: Raport Zespołu Eksperckiego z Prac w latach 2012-2016..., s. 96 i n. 
być ukształtowanie w dziedzinie stosunków prawa administracyjnego, konkretyzowanych $\mathrm{w}$ formach milczącego załatwienia sprawy, jednolitego i klarownego reżimu procesowego, z jednej strony opartego na formule ograniczenia wymagań formalnych do niezbędnego minimum, z drugiej zaś odpowiadającego cechom procesu jurysdykcyjnego z gwarancjami ochrony praw jednostki oraz praworządności. Z prakseologicznego punktu widzenia niezbędne było stworzenie regulacji procesowej odpowiadającej specyfice spraw, które niejednokrotnie, ze względu na doniosłą społecznie wagę i masową skalę, wymagały dookreślenia reguł ich prowadzenia od momentu wszczęcia aż do zakończenia, a jednocześnie nie zachodziła potrzeba bezwzględnego sprzężenia trybu ich rozpoznania ze standardem podstawowym formalizmu procesowego.

Powstaje jednak pytanie, czy tak określone warunki brzegowe wypełnia model zespolenia z k.p.a. instytucji milczącego załatwienia sprawy. Dla praktyki stosowania prawa, przy wykorzystaniu zakorzenionej już $\mathrm{w}$ aktach prawa materialnego instytucji, szczególnego znaczenia nabiera klarowność i konsekwencja w zakresie odniesienia konstrukcji procesowych rozdziału 8a działu II k.p.a. Zagadnieniem o podstawowym znaczeniu dla określenia roli kodyfikacji w zakresie sprzężenia instytucji milczącego załatwienia sprawy z Kodeksem jest bowiem nie tylko przedmiotowe wyodrębnienie sfery oddziaływania zunifikowanych rozwiązań formalnoprawnych tego aktu, ale także określenie sposobu zespolenia zagadnień procesowych zastosowania instytucji milczącego załatwienia sprawy z k.p.a.

\section{Zakres stosowania przepisów k.p.a. w sprawach załatwianych milcząco}

Dla rozważanej materii zakresu stosowania przepisów k.p.a. w sprawach załatwianych milcząco szczególnie kontrowersyjny staje się fakt, że wolą ustawodawcy było nadanie rozwiązaniom procesowym k.p.a. leżącym u podstaw zastosowania instytucji jedynie ramowego charakteru. Z uzasadnienia projektu ustawy wprowadzającej rozdział 8a do działu II Kodeksu jednoznacznie wynika, że intencją ustawodawcy jest ścisła reglamentacja zastosowania rozwiązań k.p.a. do spraw, dla których przewidziano w przepisach szczególnych formę milczącego załatwienia sprawy, poprzez zastrzeżenie konieczności dodatkowego wyraźnego - odesłania do stosowania Kodeksu w przepisach prawa 
materialnego. Z jednej zatem strony sposób zdeterminowania formy załatwienia sprawy w przepisach szczególnych, z drugiej zaś konstrukcja wyraźnego odesłania do stosowania przepisów rozdziału 8a działu II k.p.a. mają w ocenie ustawodawcy uprawniać możliwość zastosowania Kodeksu w kształcie nadanym ramami nowelizacji. Wyrazem tak określonej woli ustawodawcy ma być norma wynikająca $\mathrm{z}$ art. 122a § 1 k.p.a., w myśl której sprawa może być załatwiona milcząco, gdy przepis szczególny tak stanowi. W uzasadnieniu projektu zmiany do k.p.a. stwierdzono, że: „instytucja milczącego załatwienia sprawy w Kodeksie ma charakter ramowy, podstawę prawną zastosowania tej instytucji do konkretnych spraw stanowił będzie przepis prawa materialnego. Instytucja milczącego załatwienia sprawy znajdzie zastosowanie tylko wtedy, gdy przepis prawa materialnego wyraźnie tak będzie stanowił". Od woli ustawodawcy, wyrażonej w przepisach prawa materialnego, ma zależeć zatem to, czy przepisy k.p.a. o milczącym załatwieniu sprawy znajdą zastosowanie do spraw, dla których w aktach prawa materialnego przewidziano konstrukcję milczenia władzy - jako formę działania administracji.

Należy jednak podkreślić, że problem zakresu stosowania przepisów k.p.a. o milczącym załatwieniu sprawy oraz podstaw prawnych objęcia sprawy załatwianej milcząco reżimem Kodeksu budzi istotne wątpliwości. Elementem sporu doktrynalnego, a także sporu w judykaturze jest interpretacja normy wynikającej z art. 122a $\S 1$ k.p.a. Istota konfliktu sprowadza się zasadniczo do wyjaśnienia, czy zwrot: „sprawa może być załatwiona milcząco, gdy przepis szczególny tak stanowi" należy wiązać z koniecznością statuowania w przepisach szczególnych normy odsyłającej do stosowania k.p.a., czy odnosić jedynie do sytuacji, gdy z mocy przepisu szczególnego załatwienie sprawy powinno nastąić w tej właśnie formie ${ }^{5}$.

\footnotetext{
${ }^{5}$ Zwolennikiem tezy o zastosowaniu przepisów Kodeksu z mocy normy wynikającej z przepisu szczególnego - odsyłającej do stosowania przepisów k.p.a. o milczącym załatwieniu sprawy - jest m.in. J. Piecha. Zob.: J. Piecha, Komentarz do art. 122a k.p.a., w: Kodeks postepowania administracyjnego. Komentarz, pod red. R. Hausera, M. Wierzbowskiego, Warszawa 2017, s. 894 i n.; S. Gajewski, Kodeks postępowania administracyjnego. Nowe instytucje. Komentarz do rozdziałów 5a, 8a, 14 działów IV i VIII k.p.a., Legalis/el. 2017. Przeciwne stanowisko - oparte na twierdzeniu o dopuszczalności bezpośredniego stosowania k.p.a. do spraw załatwianych w formie milczącej, odpowiadającej cechom art. 122a $\S 2$ Kodeksu - zajmuje m.in. A. Wróbel. Zob.: A. Wróbel, Komentarz do art. 122a k.p.a., w: Kodeks postępowania administracyjnego. Komentarz, pod red. A. Wróbla, M. Jaśkowskiej,
} 
W kontekście zgłaszanych zastrzeżeń wyłaniają się co najmniej dwa istotne zagadnienia wymagające wyjaśnienia, a mianowicie: (1) kwestia ramowego charakteru regulacji kodeksowej o milczącym załatwieniu sprawy; (2) mechanizm zespolenia z k.p.a. instytucji milczącego załatwienia sprawy.

Pojęcie "ramowy", odniesione w uzasadnieniu projektu do ujętej w k.p.a. instytucji, wzbudza wątpliwości. Zakres znaczeniowy pojęcia wiąże się zazwyczaj ze sformułowaniem jakichś ogólnych zaleceń, zasad; pewnego zarysu, schematu czegoś - bez szczegółów ${ }^{6}$. W tym stanie rzeczy można dostrzec niespójność pomiędzy wyrażoną wolą a faktycznym charakterem regulacji kodeksowej. Ujęty w ramy obowiązywania k.p.a. model regulacji procesowej instytucji milczącego załatwienia sprawy jest modelem regulacji zupełnej, wyznaczającej ciąg czynności organu od momentu wszczęcia aż do zakończenia postępowania w sposób milczący. Mamy zatem w sensie prawnym do czynienia z całościową konstrukcją formalną milczącego załatwienia sprawy, która w pełni nadaje się do zastosowania jako wyłączna podstawa procesowa działania administracji z wykorzystaniem takiej instytucji. Od ustawodawcy nie oczekuje się w tym względzie żadnych form uszczegółowienia postępowania w aktach odrębnych względem k.p.a. ${ }^{7} \mathrm{~W}$ obszarze pozakodeksowym lokuje się natomiast kwestia umiejscowienia instytucji milczenia władzy, dla określenia sposobu konkretyzacji normy prawa materialnego w wyznaczonych przedmiotowo kategoriach spraw.

Innym aspektem zagadnienia związanego ze stosowaniem przepisów rozdziału 8a działu II k.p.a. jest artykułowany przez ustawodawcę mechanizm objęcia reżimem Kodeksu spraw załatwianych milcząco. Z uzasadnienia projektu wynika, że ustawodawca zamierza ograniczyć możliwość stosowania k.p.a. w powyższym zakresie warunkiem prawnym - obowiązywania normy prawa materialnego o charakterze

\footnotetext{
Warszawa 2018, s. 780; W. Chróścielewski, J.P. Tarno, P. Dańczak, Postępowanie administracyjne i postępowanie przed sądami administracyjnymi, Warszawa 2018, s. 193.

${ }^{6}$ Por. Słownik jezzyka polskiego PWN, t. 3, Warszawa 1981.

${ }^{7} \mathrm{Na}$ cechy modelu regulacji ramowej zwraca uwagę Z. Kmieciak, wskazując przykłady ustaw szwedzkich z lat 1971 i 1986, włoskiej ustawy z 1990 r. oraz greckiego Kodeksu postępowania administracyjnego z 1999 r. Autor zauważa, że w modelu regulacji ramowej mamy do czynienia nie tyle $z$ aktami reglamentacji procesowej, ile raczej z zespołem zasad, których stosowanie pozwala na oczekiwaną przez projektodawców elastyczność działań administracji. Można je utożsamiać z pewnych zespołem zaleceń, na wzór europejskiego soft law. Zob. Z. Kmieciak, Wstęp, w: Postępowanie administracyjne w Europie, pod red. Z. Kmieciaka, Kraków 2005, s. 10.
} 
odsyłającym do stosowania k.p.a. Należy jednak podkreślić, że wykładnia art. 122a $\S 1$ k.p.a. wzbudza, w kontekście tak zakreślonego celu, uzasadnione wattpliwości. Powstaje zasadnicze pytanie, czy w istocie ratio legis leżące u podstaw wprowadzenia i sposobu zespolenia instytucji z k.p.a. zostało dostatecznie precyzyjnie wyrażone językiem normy prawnej.

Znaczenie decydujące i przydatne dla podjętej analizy ma wyznaczenie zakresu znaczeniowego pojęcia "sprawa”, o której mowa $\mathrm{w}$ art. 122a $\S 1$ k.p.a. Punktem wyjścia będzie wskazanie, czy pojęcie "sprawa" w znaczeniu, jakie nadaje mu norma wynikająca z art. 122a § 1 k.p.a., jest kategorią prawa formalnego czy kategorią prawa materialnego. Rozstrzygnięcie kwestii proceduralnego lub materialnoprawnego charakteru sprawy będzie miało istotny wpływ na określenie sposobu prawnego zdeterminowania możliwości stosowania przepisów k.p.a. Zgodnie z art. 1 pkt 1 k.p.a. przedmiotem regulacji Kodeksu w części działów I i II k.p.a. jest postępowanie przed organami administracji publicznej w należących do właściwości tych organów sprawach indywidualnych rozstrzyganych $\mathrm{w}$ drodze decyzji administracyjnej albo załatwianych milcząco. Warunków stosowania k.p.a. w praktyce działania organów administracji publicznej należy zatem upatrywać w takich przepisach, które przesądzają o charakterze sprawy - określonej jako indywidualna, konieczności jej załatwienia poprzez rozstrzygnięcie organu, z jednoczesnym zastrzeżeniem, że owo rozstrzygnięcie przybiera z mocy tych przepisów postać prawną decyzji administracyjnej lub formę milczącego załatwienia sprawy.

Przepis art. 1 pkt 1 k.p.a., wyznaczający przedmiot regulacji kodeksowej, odwołuje się zatem do kategorii spraw opatrzonych kwalifikatorem „indywidualna”. Uniwersalizująca formuła art. 1 pkt 1 k.p.a. dla przedmiotowego wyodrębnienia kategorii spraw, do których należy stosować k.p.a., powoduje zatem, że nie tylko w świetle art. 1 pkt 1 k.p.a., ale również na mocy art. 122a § 1 k.p.a. kluczowe znaczenie w określaniu zakresu stosowania k.p.a., w części rozdziału 8a działu II Kodeksu, ma wskazanie przez ustawodawcę na pojęcie sprawy indywidualnej, powiązanej dodatkowo z elementami konstrukcyjnymi odnośnie do rodzaju i właściwości organu oraz prawnej formy załatwienia sprawy przez milczenie administracji.

Zgodnie $\mathrm{z}$ poglądami utrwalonymi $\mathrm{w}$ doktrynie sprawa o charakterze indywidualnym jest definiowana poprzez odwołanie do przepisów prawa materialnego, jako prawa przedmiotowego, które określa 
konsekwencje normy prawa administracyjnego w stosunku do określonego podmiotu i ze względu na określone fakty. W. Dawidowicz stwierdza, że niepowtarzalny splot elementów indywidualnych i konkretnych tworzy sprawę administracyjną; przy czym aby sprawa administracyjna w znaczeniu materialnoprawnym mogła się urzeczywistnić, trzeba, by w wyniku wszczęcia postępowania administracyjnego stała się przedmiotem postępowania zmierzającego do rozstrzygnięcia przez ustalenie wiążących konsekwencji normy przedmiotowej ${ }^{8}$. Według stanowiska $\mathrm{T}$. Wosia sprawą o charakterze indywidualnym stanowiącą przedmiot postępowania administracyjnego będzie przewidziana $\mathrm{w}$ przepisach materialnego prawa administracyjnego możliwość konkretyzacji wzajemnych uprawnień i obowiązków podmiotów stosunku administracyjnoprawnego, którymi sa, z jednej strony, organ administracji publicznej, z drugiej zaś konkretny, indywidualny podmiot, niezwiązany z organem węzłem zależności organizacyjnej ani podległości służbowej. Należy przy tym zaznaczyć, że byt sprawy o charakterze indywidualnym jest uprzedni i samoistny, niezależny od ewentualnego wdrożenia postępowania administracyjnego. Sprawa powstaje w momencie zaistnienia przesłanek faktycznych, określonych w hipotezie normy prawnej stanowiącej o zastosowaniu normy przedmiotowej na drodze rozstrzygnięcia o określonych uprawnieniach lub obowiązkach. W powyższym ujęciu sprawa indywidualna to nic innego niż pewien stan faktyczny, wiążący się ściśle $z$ interesem prawnym indywidualnego podmiotu i wymagający ustalenia przez administrację jego konsekwencji poprzez określenie po stronie podmiotu sytuacji prawnej w postaci udzielenia lub odmowy udzielenia uprawnienia ${ }^{9}$. Elementem dopełniającym sposób rozumienia sprawy indywidualnej jest konieczność wskazania na konkretny, imiennie oznaczony podmiot, będący adresatem abstrakcyjnej i generalnej normy, która podlega konkretyzacji w okolicznościach konkretnego stanu faktycznego ${ }^{10}$.

${ }^{8}$ W. Dawidowicz, Postępowanie administracyjne. Zarys wykładu, Warszawa 1983, s. 30.

${ }^{9}$ Zob. bliżej T. Woś, Pojęcie "sprawy" w przepisach kodeksu postępowania administracyjnego, "Acta Universitatis Wratislaviensis. Prawo CLXVIII” 1990, s. 329-335. Zob. też: W. Dawidowicz, Zarys procesu administracyjnego, Warszawa 1989, s. 7-11; T. Kiełkowski, Sprawa administracyjna, Kraków 2004, s. 32-36.

${ }^{10}$ Za powyższym dopełnieniem przesłanek określenia pojęcia "sprawy indywidualnej”, a w konsekwencji wyznaczenia zakresu obowiązywania k.p.a. opowiada się L. Żukowski, Zakres obowiązywania Kodeksu postępowania administracyjnego, w: Postępowanie administracyjne i postępowanie przed Naczelnym Sadem Administracyjnym, pod red. L. Żukowskiego, R. Sawuły, Warszawa 2002, s. 41. Zob. też: J. Jendrośka, Zakres 
W literaturze przedmiotu pojęcie "sprawa indywidualna" jest odnoszone również do kategorii interesu prawnego. W powyższym ujęciu sprawa indywidualna to oparty na przepisach prawa interes prawny podmiotu uzasadniający żądanie od organu administracji publicznej udzielenia określonego uprawnienia albo oparta na tym samym prawie kompetencja organu do władczego oddziaływania na interes prawny podmiotu poprzez wiążące nałożenie obowiązku ${ }^{11}$. Tak rozumiana sprawa staje się przedmiotem postępowania administracyjnego z chwilą zainicjowania procesu przed organem administracji publicznej. Rola norm procesowych k.p.a. eksponuje doniosłość sprawy objętej przedmiotem związania Kodeksu, zważywszy na fakt, że ustawodawca narzuca organowi tryb, w jakim powinien on rozstrzygać sprawę.

Kodeks, co do zasady, normuje postępowanie w sprawach, które mają charakter administracyjny, tzn. reguluje taki stosunek prawny, w którym jednym z uczestników jest organ administracji publicznej w znaczeniu zarówno ustrojowym, jak i funkcjonalnym, właściwy do załatwienia sprawy w formie prawnej decyzji lub w formie milczącej, a podstawą prawną kształtowania stosunku są przepisy powszechnie obowiązującego prawa administracyjnego. Można zatem przyjąć, że takie administracyjne sprawy indywidualne, które z wyraźnej woli ustawodawcy mają być rozstrzygane decyzją lub poprzez milczenie organu usytuowanego w strukturze administracyjnej państwa lub innego zrównanego z nim w uprawnieniach orzeczniczych, mogą być objęte reżimem przepisów Kodeksu, w tym przepisów rozdziału 8a działu II k.p.a. w zakresie spraw załatwianych milcząco.

Należy jednak uwzględnić, że administracyjny charakter sprawy nie może być tutaj kryterium kwalifikacji prawnej. Ustawodawca przewiduje niekiedy właściwość sądów powszechnych i tryb k.p.c. ${ }^{12}$ dla rozpatrzenia spraw, które w płaszczyźnie materialnoprawnej mają charakter administracyjny, i odwrotnie, poddaje spory ze stosunków cywilnych właściwości organów administracyjnych oraz regulacji k.p.a. ${ }^{13}$

obowiąywania K.p.a. w postępowaniach szczególnych, "Gospodarka i Administracja Terenowa" 1967, nr 2, s. 41; T. Woś, op. cit., s. 334.

${ }^{11}$ Por. W. Dawidowicz, Postepowania w sprawach administracyjnych a postępowanie przed sądem cywilnym, "Państwo i Prawo” 1990, z. 7, s. 42.

${ }^{12}$ Ustawa z dnia 17 XI 1964 r. Kodeks postępowania cywilnego (tekst jedn. Dz.U. 2018, poz. 1360 ze zm.).

${ }^{13}$ Por. J. Starościak, Rozgraniczenie kompetencji sądów i organów administracji, w: Funkcjonowanie administracji w świetle orzecznictwa, pod red. J. Starościaka, J. Łętowskiego, Warszawa 1967, s. 11-13. 
Jak już zaznaczono, określenie sprawy indywidualnej jako przedmiotu postępowania według reguł k.p.a. wymaga dodatkowego wskazania na rodzaj i właściwość organu oraz prawną formę jej załatwienia, które spełnione łącznie wyznaczają zakres stosowania Kodeksu. Dla oznaczenia rodzaju organu k.p.a. posługuje się w art. 1 pkt 1 pojęciem „organ administracji publicznej", uzupełniając w art. 1 pkt 2 k.p.a. katalog podmiotów o inne organy państwowe i podmioty, które z mocy prawa lub na podstawie zawartych porozumień zostały powołane do załatwiania spraw indywidualnych w formie prawnej decyzji administracyjnej lub $\mathrm{w}$ formie milczącej.

Pozytywnoprawne dookreślenie zakresu znaczeniowego pojęcia "organ administracji publicznej" statuuje art. $5 \S 2$ pkt 3 k.p.a., zgodnie z którym pod pojęciem "organ administracji publicznej” należy rozumieć: ministrów, centralne organy administracji rządowej, wojewodów, działające w ich lub we własnym imieniu inne terenowe organy administracji rządowej - zespolonej i niezespolonej, organy jednostek samorządu terytorialnego oraz organy i podmioty wymienione w art. 1 pkt 2 k.p.a. Kodeks posługuje się definicją legalną organu administracji publicznej, stworzoną wyłącznie na użytek stosowania przepisów k.p.a.; jednocześnie, analogicznie jak w procesie decyzyjnego działania organu, również w warunkach milczącego załatwienia sprawy stosowanie prawa powierza się organom w znaczeniu ustrojowym i funkcjonalnym. Uprawnienie do załatwienia sprawy indywidualnej musi wynikać z wyraźnej podstawy ustawowej i mieć charakter kompetencji szczególnej, czyli ustanowionej w odniesieniu do określonego przedmiotowo rodzaju spraw ${ }^{14}$.

Istotnym elementem strony przedmiotowej związania k.p.a. jest także prawna forma działania stosowana przez organy administracji publicznej do rozstrzygania spraw indywidualnych. Zgodnie z art. 1 pkt 1 k.p.a., w brzmieniu po nowelizacji, Kodeks znajduje zastosowanie wówczas, gdy normy prawa administracyjnego, wymagające władczej i jednostronnej konkretyzacji względem indywidualnie oznaczonego podmiotu zewnętrznego, zastrzegają działanie organu w formie prawnej decyzji administracyjnej lub w formie milczącego załatwienia sprawy. W rozważaniach nad zagadnieniem stosowania k.p.a. w sprawach załatwianych milcząco wyznaczenie charakteru prawnego i cech działań administracji, którym można przypisać znamiona milczącego

14 Por. W. Dawidowicz, Z problematyki decyzji organów administracji państwowej w świetle orzecznictwa NSA, "Państwo i Prawo" 1984, z. 3, s. 6 i n.; zob. też K.M. Ziemski, Indywidualny akt administracyjny jako forma prawna działania administracji, Poznań 2005, s. 238. 
załatwienia sprawy, ma zatem przesądzające znaczenie dla określenia zakresu związania k.p.a.

Na podkreślenie zasługuje fakt, że Kodeks w art. 1 pkt 1 odwołuje się do działania organu $\mathrm{w}$ formie prawnej milczącego załatwienia sprawy, nie przesądza natomiast expressis verbis, jakie działanie można uznać za załatwienie sprawy w formie milczącej. Artykuł 1 pkt 1 k.p.a. stanowi jedynie o tym, że jeżeli określone zachowanie organu mające znaczenie prawne w sprawie indywidualnej może być z mocy przepisu szczególnego kwalifikowane w kategorii milczącego załatwienia sprawy, to zastosowanie znajduje k.p.a. Z drugiej jednak strony to k.p.a. jest jedynym aktem prawnym, z którego można, przy zastosowaniu złożonych zabiegów interpretacyjnych, wyprowadzić normatywne pojęcie milczącego załatwienia sprawy, ale tylko w takim aspekcie odniesienia, który będzie uprawniał możliwość zastosowania Kodeksu. Przydatny w tym względzie jest art. 122a § 2 k.p.a., zgodnie z którym „sprawę uznaje się za załatwioną milcząco w sposób w całości uwzględniający żądanie strony, jeżeli w terminie miesiąca od dnia doręczenia żądania strony właściwemu organowi administracji publicznej albo w innym terminie określonym w przepisie szczególnym organ ten: 1) nie wyda decyzji lub postanowienia kończącego postępowanie w sprawie (milczące zakończenie postępowania) albo 2) nie wniesie sprzeciwu w drodze decyzji (milcząca zgoda)". Artykuł 122a § 2 k.p.a. opiera instytucję milczącego załatwienia sprawy na formule fikcji prawnej wynikającej z założenia, że sprawa została załatwiona w sposób zgodny z żądaniem strony w wyniku zdarzenia prawnego w postaci upływu terminu, choć nie zostało w sposób konwencjonalny podjęte rozstrzygnięcie.

Jednocześnie w myśl art. 1 pkt 1 k.p.a. milczenie administracji stanowi - obok decyzji - formę rozstrzygnięcia sprawy indywidualnej przez organ administracji publicznej, w czym dodatkowo utwierdza art. 110 $\S 2$ k.p.a., zgodnie z którym organ administracji publicznej w przypadku milczącego załatwienia sprawy jest związany wydanym w tym trybie rozstrzygnięciem. Milczenie administracji jest zatem jednym ze sposobów załatwienia sprawy w procesie jurysdykcyjnym, w którym sam fakt milczenia jest procesową formą wyniku postępowania, przybierającą postać niewyrażonego aktu konkludentnego ${ }^{15}$. Cechą właściwą takiego

${ }_{15}$ Zwolennikiem teorii aktu administracyjnego konkludentnego, w ślad za przedstawicielami doktryny niemieckiej, jest B. Majchrzak, Procedura zgłoszenia robót budowlanych, Warszawa 2008, s. 85 i n.; zob. też A. Wróbel, Rozdział 8a. Milczące załatwienie sprawy, 
aktu jest brak konwencjonalnego uzewnętrznienia woli i jej zakomunikowania stronie.

W podsumowaniu uwag można zatem stwierdzić, że kodeksowe pojęcie "sprawa”, w każdej z konfiguracji prawnych, ma wymiar materialny, lokujący zagadnienie przedmiotu regulacji Kodeksu w warstwie przepisów administracyjnego prawa materialnego. Ilekroć w przepisach k.p.a. jest mowa o „sprawie”, należy przez nią rozumieć splot konkretnych i indywidualnych elementów przedmiotowych i podmiotowych, zdeterminowanych normą prawa materialnego, dopełnionych charakterem prawnym organu kompetentnego do jej załatwienia oraz formą prawną działania organu.

Dla rozważenia kwestii stosowania przepisów k.p.a. o milczącym załatwieniu sprawy istotny pozostaje także problem umiejscowienia pojęcia "załatwienie sprawy". W tym zakresie przesądzające znaczenie będzie miało stwierdzenie, czy k.p.a., odwołując się w art. 122a § 1 k.p.a. do pojęcia "załatwiona milcząco", sytuuje to pojęcie w obszarze prawa procesowego czy materialnego.

Interpretacji pojęcia wyprowadzonego z art. 122a § 1 k.p.a. należy dokonywać analogicznie jak przy rozważaniach nad pojęciem "sprawa", w związku z art. 1 pkt 1 Kodeksu. Zgodnie z art. 122a § 1 k.p.a. sprawa może być załatwiona milcząco, gdy przepis szczególny tak stanowi; natomiast w myśl art. 1 pkt 1 Kodeksu, gdy przepis szczególny statuuje po stronie organu administracji publicznej kompetencję do załatwienia sprawy, z zastrzeżeniem formy milczącej, to stosuje się k.p.a. W obu przypadkach ustawodawca posługuje się tożsamą nomenklaturą prawną, tj. pojęciem "sprawa załatwiana milcząco". Sprawy załatwiane to takie, co do których organ ma kompetencję do władczego wypowiedzenia się w danym przedmiocie, poprzez ukształtowanie treści sytuacji administracyjnoprawnej ${ }^{16}$. Dla załatwienia sprawy ustawodawca zastrzega $\mathrm{w}$ aktach prawa materialnego różne formy. Może to nastąpić wprost, np. poprzez wydanie decyzji stanowiącej rozstrzygnięcie o istocie sprawy, lub w sposób dorozumiany - przy zastosowaniu instytucji milczącego załatwienia sprawy, również kwalifikowanego jako sposób rozstrzygnięcia. Treścią aktu, zarówno w formie konwencjonalnej - decyzji, jak i aktu konkludentnego, będzie załatwienie sprawy, $\mathrm{tj}$. wyznaczenie wiążących konsekwencji normy prawa materialnego dla danego stanu

w: Kodeks postępowania administracyjnego. Komentarz, pod red. A. Wróbla, M. Jaśkowskiej, Warszawa 2018, s. 777.

${ }^{16}$ Bliżej na ten temat por. K.M. Ziemski, op. cit., s. 232 i n. 
faktycznego ${ }^{17}$. Pojęcie "załatwienie” ma także swoje konotacje formalne - jest stosowane dla oznaczenia zakończenia sprawy ${ }^{18}$.

Regulacja k.p.a. w zakresie objętym przepisami rozdziału 8a działu II Kodeksu będzie zatem normowała postępowanie w przypadku załatwiania przez organ administracji publicznej: (1) spraw indywidualnych; (2) spraw wymagających dla ich załatwienia rozstrzygnięcia; (3) spraw, $\mathrm{w}$ których rozstrzygnięcia przybierają z mocy przepisu szczególnego postać milczącego załatwienia sprawy ${ }^{19}$.

W konsekwencji brzmienie przepisu art. 122a § 1 k.p.a. - „sprawa może być załatwiona milcząco, gdy przepis szczególny tak stanowi" - uprawnia twierdzenie, że przepis szczególny ma statuować dla załatwienia sprawy formę prawną milczenia władzy oraz powierzać kompetencję do takiego sposobu konkretyzacji normy prawa materialnego organowi administracji publicznej. Tak określone cechy wyznaczą sprawę, jako przedmiot postępowania objęty regulacją k.p.a. w warstwie procesowej instytucji milczącego załatwienia sprawy, z chwilą wszczęcia postępowania.

Oczywiście, zupełnie innym aspektem zagadnienia jest zakres odnoszonej regulacji kodeksowej. Nie ulega bowiem wątpliwości, że Kodeks jako lex generalis określa poziom relacji pomiędzy przepisami ogólnymi k.p.a. a regulacją procesową o charakterze szczególnym zawartą w przepisach ustaw odrębnych. W tym stanie rzeczy do spraw załatwianych milcząco stosuje się z mocy art. 1 pkt 1 k.p.a. przepisy rozdziału 8a działu II Kodeksu w zakresie, w jakim przepisy ustaw szczególnych nie ustalają własnych, odmiennych zasad postępowania w tych sprawach.

\section{Instytucja milczącego załatwienia sprawy w k.p.a. - istota $i$ charakter prawny}

Podstawowym warunkiem załatwienia sprawy w sposób milczący jest żądanie strony, wyznaczające zakres związania organu w sprawie, w której postępowanie można zakończyć milcząco w rozumieniu art. 122a § 2 pkt 1 k.p.a., lub nadające kształt jej uprawnieniom w przypadku milczącej

${ }^{17}$ Por. J. Borkowski, Komentarz do art. 104 k.p.a., w: Kodeks postepowania administracyjnego. Komentarz, pod red. B. Adamiak, J. Borkowskiego, Warszawa 2016, s. 417 i n.; zob. też J. Zimmermann, Polska jurysdykcja administracyjna, Warszawa 1996, s. 134 i n.

${ }^{18}$ Por. K.M. Ziemski, op. cit., s. 232.

${ }^{19} \mathrm{Z}$ zastrzeżeniem, że będzie to działanie wyczerpujące znamiona milczącego załatwienia sprawy $w$ rozumieniu art. 122a $\S 2$ k.p.a. 
zgody w rozumieniu art. 122a $\S 2$ pkt 2 k.p.a. Wola strony wyrażona żądaniem jest zatem elementem konstytutywnym załatwienia sprawy w sposób milczący, ponieważ: (1) milczące załatwienie sprawy ze swej istoty jest dopuszczalne tylko $\mathrm{w}$ postępowaniu wszczętym $\mathrm{z}$ inicjatywy strony; (2) treścią załatwienia sprawy w sposób milczący, zgodnie z regulacją k.p.a., jest uwzględnienie w całości żądania strony; (3) wniesienie żądania określa początkową datę biegu terminu na wydanie decyzji lub postanowienia kończącego postępowanie w sprawie albo wniesienia sprzeciwu, z zastrzeżeniem zastosowania art. 64 k.p.a. Treść żądania wyznacza przy tym stosowaną normę prawa materialnego oraz procesowego, które mają znaczenie dla ustalenia kompetencji organu do załatwienia sprawy w formie milczącej; zakresu i przedmiotu postępowania administracyjnego oraz wynikających z tych przepisów konsekwencji prawnych. Fakty objęte przedmiotem żądania wraz ze stosowaną normą prawną przesądzają o pełnym kształcie uprawnienia strony. Brak werbalnego wyrażenia woli w terminie ustawowym w następstwie przeprowadzonego postępowania jest zatem sposobem wykonywania kompetencji organu administracji publicznej do załatwienia sprawy w sposób milczący poprzez jej rozstrzygnięcie kończące postępowanie w sprawie w warunkach, w których organ nie znajduje podstaw do wydania decyzji, postanowienia kończącego postępowanie albo wniesienia sprzeciwu ${ }^{20}$.

W powyższym ujęciu milczące załatwienie sprawy poprzez zaniechanie działania stanowi sposób finalizacji procesu stosowania prawa. Taka forma zakończenia postępowania nie jest przy tym równoznaczna z dopuszczeniem prawnej możliwości powstrzymania się przez organ od podejmowania jakichkolwiek czynności proceduralnych w wyznaczonym terminie, lecz wiąże się wyłącznie z powstrzymaniem od uzewnętrznienia woli co do końcowego sposobu rozpatrzenia sprawy w celu osiągnięcia założonego rezultatu w tych sprawach, w których ustawodawca ustanowił po stronie organu wyraźną kompetencję dla takiego sposobu konkretyzacji normy prawa materialnego.

Zasadnicza przesłanka milczącego załatwienia sprawy w postaci upływu terminu do wydania decyzji, postanowienia kończącego postępowanie w sprawie lub do wniesienia sprzeciwu doznaje swoistego ograniczenia jedynie w normie wynikającej z art. 122c § 1 zd. 2 k.p.a., a zatem w sytuacji, gdy organ, nie czekając na upływ terminu końcowego, zawiadamia stronę o braku sprzeciwu. Instytucja zawiadomienia

${ }^{20}$ Por. A. Wróbel, Komentarz do art. 122 a k.p.a., s. 783-785. 
o braku sprzeciwu ma umożliwić organowi szybsze ukształtowanie praw jednostki, bez konieczności oczekiwania na upływ terminu, z którym przepis łączy załatwienie sprawy w sposób milczący. W treści zawiadomienia, które wywołuje skutek milczącego załatwienia sprawy z chwilą doręczenia stronie, organ komunikuje stronie brak podstaw prawnych do wniesienia sprzeciwu.

Ustawodawca oparł instytucję milczącego załatwienia sprawy na fikcji prawnej zarówno w wymiarze materialnym, jak i formalnym. Zdarzenie prawne, jakim z założenia ma być świadome skorzystanie przez organ $\mathrm{z}$ kompetencji do milczenia w określonym terminie, pozwala z mocy prawa na uznanie, iż organ oświadczył swoją wolę w ten sposób i w tej treści, że w ujęciu formalnym wydał rozstrzygnięcie, a w ujęciu materialnym załatwił sprawę co do jej istoty w sposób w całości uwzględniający żądanie strony ${ }^{21}$.

W następstwie poczynionych uwag w toku dalszych rozważań można się zatem zastanawiać nad tym, czy fakt oparcia kodeksowej instytucji milczącego załatwienia sprawy na koncepcji fikcji prawnej w jej aspekcie formalnym i materialnym pozwala konsekwentnie na przyjęcie, że k.p.a. zakreśla pojęcie "milczące załatwienie sprawy" tak w znaczeniu materialnym, jak i formalnym.

Po pierwsze, z istoty zastosowania instytucji milczącego załatwienia sprawy wynika skutek prawny załatwienia sprawy indywidualnej w rozumieniu art. 1 pkt 1 k.p.a., a zatem autorytatywna konkretyzacja praw i obowiązków określonych ustawą przez organ administracji publicznej. Po drugie, milczące załatwienie sprawy jest prawną formą rozstrzygnięcia wywołującego skutek procesowy zakończenia postępowania przed danym organem administracji publicznej. Milczące załatwienie sprawy może być zatem kwalifikowane jako jednostronna czynność organu administracji publicznej wyrażająca się w powstrzymaniu od wydania decyzji administracyjnej lub postanowienia kończącego postępowanie w sprawie, a jednocześnie określająca konsekwencje stosowanej w sprawie normy prawnej w odniesieniu do konkretnie oznaczonego adresata. Bez znaczenia pozostaje przy tym fakt wyróżnienia przez ustawodawce formy milczącego zakończenia postępowania, gdy organ nie wyda w terminie decyzji lub postanowienia kończącego postępowanie w sprawie albo milczącej zgody, gdy nie wniesie sprzeciwu w drodze decyzji. W obu przypadkach mamy do czynienia z milczącym załatwieniem sprawy, które

\footnotetext{
${ }^{21}$ Ibidem, s. 776-779.
} 
rozstrzyga sprawę co do jej istoty, a jednocześnie kończy postępowanie w sprawie ${ }^{22}$. Wykładnia art. 1 pkt 1 k.p.a. w zw. z art. 122a § 2 k.p.a. skłania do przyjęcia stanowiska, iż Kodeks statuuje procesowe pojęcie milczącego załatwienia sprawy poprzez odniesienie do cech wskazanego sposobu finalizacji postępowania, jako procesowej formy wyniku postępowania podejmowanego na drodze zmierzającej do zastosowania normy prawa materialnego względem indywidualnie oznaczonego podmiotu zewnętrznego, w jego konkretnie oznaczonej sprawie; jednocześnie określa materialnoprawne konsekwencje zdarzenia prawnego, jakim jest upływ określonego terminu, poprzez odwołanie do konstrukcji fikcji pozytywnego rozstrzygnięcia. Kodeks za sprawą art. 122a § 2 konkretyzuje zatem cechy formalne zachowań organu oraz ich materialnoprawne konsekwencje - wyrażone konstrukcją fikcji pozytywnego rozstrzygnięcia, dla oznaczenia form aktywności administracji poddanych reżimowi k.p.a. Ponadto Kodeks, mocą art. 1 pkt 1 oraz art. 122a § 2, wyznacza system wzajemnych zależności pomiędzy milczeniem władzy, uznanym za kwalifikowany wynik postępowania określony reżimem k.p.a., a przepisami prawa materialnego, które wiążą z zaniechaniem działań organu konsekwencje w postaci określonego skutku prawnego opartego na konstrukcji fikcji pozytywnego rozstrzygnięcia.

Opowiedzenie się za koncepcją poddania reżimowi k.p.a. instytucji milczącego załatwienia sprawy, wykazującego cechy określone art.122a $\S 2$ k.p.a., przesądza zatem o tym, że Kodeks znajduje zastosowanie w przypadkach, w których z przepisów prawa materialnego wynikać będzie dla organu kompetencja do załatwienia sprawy w formie milczącej, opartej na konstrukcji fikcji pozytywnego rozstrzygnięcia. Samo zdeterminowanie formy załatwienia sprawy w przepisach szczególnych jest wystarczające dla przyjęcia mocy wiążącej Kodeksu, bez potrzeby odrębnego statuowania w tych przepisach klauzuli odsyłającej do stosowania k.p.a. ${ }^{23}$ Oczywiście, w każdym przypadku zastosowania instytucji kodeksowej milczącego załatwienia sprawy należy brać pod

${ }^{22}$ Ibidem, s. 782-785.

${ }^{23}$ Stanowisko takie prezentuje m.in. A. Wróbel, podnosząc, że określenie "jeżeli przepis szczególny tak stanowi" należy rozumieć w ten sposób, iż obowiązuje przepis szczególny, który organowi administracji publicznej przyznaje kompetencję do milczącego załatwienia sprawy. Ocena, czy przepis szczególny upoważnia do milczącego załatwienia sprawy, powinna być dokonywana z uwzględnieniem treści art. 122a § 2 k.p.a. Jednocześnie autor, odwołując się m.in. do przepisu art. 11 ust. 9 Ustawy z dnia 2 lipca 2004 o swobodzie działalności gospodarczej, dopuszcza możliwość stosowania przepisów rozdziału 8a Kodeksu do stanów prawnych zastanych w dniu wejścia w życie 
uwagę regułę interpretacyjną lex specialis derogat legi generali. Nie można bowiem tracić z pola widzenia faktu, że regulacje szczególne posługujące się formą milczącego załatwienia sprawy mogą być na tyle zupełne, że nie pozostawią przestrzeni dla stosowania k.p.a. lub znacznie ograniczą zakres stosowanej regulacji kodeksowej. Nie zmienia to jednak ogólnej reguły związania k.p.a. w sprawach, dla których z przepisów prawa materialnego wynika forma działania o cechach wskazanych $\mathrm{w}$ art. 122a $\S 2$ k.p.a. Przyjęcie innego twierdzenia mogłoby doprowadzić do nieuzasadnionego i pozbawionego logicznych podstaw różnicowania pozycji procesowej stron w sprawach załatwianych milcząco w sposób wyczerpujący znamiona art. 122a § 2 k.p.a. Co więcej, stan, w którym ustawodawca reglamentowałby dostęp do procedury uregulowanej w k.p.a. w części rozdziału 8a działu II Kodeksu poprzez klauzulę podwójnych odesłań, tj. z jednej strony z mocy art. 1 pkt 1 k.p.a. dekretowanych wyrażoną $\mathrm{w}$ przepisach prawa materialnego wolą załatwienia sprawy w formie milczącej, z drugiej zaś regułą wyraźnych odesłań do stosowania k.p.a. statuowanych mocą przepisu szczególnego, z dodatkowym zastrzeżeniem cech działania administracji wyartykułowanych $\mathrm{w}$ art. 122a $\S 2$ k.p.a., stwarzałby w istocie iluzję jednolitego normowania, a samemu zabiegowi ustawodawcy należałoby przypisać walor czysto deklaratywny - osłabiający w konsekwencji ochronną i porządkującą funkcję, jaką k.p.a. ma wypełniać w porządku prawa administracyjnego ${ }^{24}$.

\section{Problem intertemporalności a zagadnienie mocy wiążącej w czasie przepisów k.p.a. o milczącym załatwieniu sprawy}

W rozważaniach nad zagadnieniem stosowania k.p.a. w sprawach załatwianych milcząco otwarty pozostaje jeszcze problem zastosowania

nowelizacji". Por. A. Wróbel, Komentarz do art. 122a k.p.a., s. 780; zob. też W. Chróścielewski, J.P. Tarno, P. Dańczak, op. cit., s. 193.

${ }^{24}$ Trybunał Konstytucyjny (TK) w wyroku z 8 I 2013 r., sygn. K 18/10, OTK-A 2013, nr 1, poz. 2, stwierdził, że ustawodawca nie może tworzyć konstrukcji normatywnych, które są niewykonalne, stanowią złudzenie prawa i w konsekwencji dają jedynie pozór ochrony interesów jednostki. Zob. też: wyrok TK z 19 XII 2002 r., sygn. K 33/02, OTK-A 2002, nr 7, poz. 97, oraz wyrok TK z 10 I 2012 r., sygn. P 19/10, OTK-A 2012, nr 1, poz. 2. Bliżej na temat wywodzonej z art. 2 Konstytucji RP zasady jednoznaczności prawa i zakazu tworzenia uprawnień pozornych por. P. Tuleja, Komentarz do art. 2 Konstytucji RP, w: Konstytucja RP, t. 1: Komentarz do art. 1-86, pod red. M. Safjana, L. Boska, Warszawa 2016, s. 224 i n. 
kodeksowej instytucji milczącego załatwienia sprawy do stanów prawnych zastanych na dzień wejścia w życie nowelizacji. W uzasadnieniu zmian wprowadzanych do k.p.a. eksponowano doniosłość roli Kodeksu w porządkowaniu materii spraw administracyjnoprawnych załatwianych w formach milczących. Wytaczane argumenty opierano na potrzebie objęcia tych instytucji, które w sposób dość intensywny i samorzutny pojawiają się w prawie materialnym ${ }^{25}$. U podstaw koncepcji objęcia instytucji regulacją k.p.a. leżała potrzeba uporządkowania i usystematyzowania istniejących $\mathrm{w}$ prawie materialnym rozwiązań, regulowanych dotąd przez ustawodawcę w sposób - jak się wydaje dość przypadkowy i nie do końca przemyślany.

Poglądy wyrażane w literaturze przedmiotu wskazują jednak, że kwestia ta nie jest tak oczywista. Postawiono m.in. tezę, że z normy art. 122a $\S 1$ k.p.a. wynika wprost, że w ujęciu proceduralnym ze sprawą załatwianą milcząco mamy do czynienia tylko wtedy, gdy przepis szczególny tak stanowi, a zatem wówczas, gdy w przepisach prawa materialnego ustawodawca wyraźnie umieści odesłanie do stosowania trybu określonego w rozdziale 8a działu II Kodeksu. Do momentu, w którym w poszczególnych aktach normatywnych takiego przepisu szczególnego nie będzie, nie sposób mówić o mocy wiążącej k.p.a. w zakresie milczącego załatwienia sprawy. Jednocześnie pojawiają się jednoznaczne twierdzenia, że do przypadków już funkcjonujących regulacji materialnoprawnych zakładających milczące załatwienie sprawy, a zatem do stanów prawnych zastanych i w naturalny sposób predestynowanych do ewentualnego objęcia k.p.a., przepisy rozdziału 8a działu II Kodeksu będą mogły w przyszłości znaleźć zastosowanie, jeżeli ustawodawca dokona w aktach prawa materialnego wyraźnego zastrzeżenia o dopuszczalności jego stosowania ${ }^{26}$.

Ustosunkowując się do tak postawionego problemu, należy zwrócić uwagę na istotę procesów kodyfikacyjnych. W systemach prawnych posiadających skodyfikowane administracyjne prawo procesowe kodyfikacja wyznacza podstawowy standard i stały punkt odniesienia dla ocen i reguł wykładni instytucji formalnego prawa administracyjnego; zakreśla ogólny, a jednocześnie podstawowy i ustabilizowany wzorzec poprawności działania w określonej materii stosunków administracyjnoprawnych. W swym założeniu podstawowym ukierunkowana jest

\footnotetext{
${ }^{25}$ Por. W. Gurba, op. cit., s. 96 i n.

${ }^{26}$ J. Piecha, Komentarz do art. 122 a k.p.a., s. 894 i n.
} 
na sformalizowanie zespołu czynności zmierzających do określonego skutku prawnego; w efekcie wtórnym stwarza gwarancje ochrony praw i interesów jednostkowych ${ }^{27}$. Wypełnia więc rolę porządkującą i względnie ujednolicającą model stosowania prawa w formach określonych przedmiotem jej związania. Objęcie instytucji milczącego załatwienia sprawy aktem takiej rangi determinuje zatem wykładnię celowościową przepisów, zmierzającą do przyjęcia twierdzenia, że k.p.a., będąc aktem wypełniającym funkcje uniwersalizujące, powinien znaleźć zastosowanie, jako lex generalis, zarówno do wprowadzanych, jak i już funkcjonujących instytucji w obrębie prawa materialnego. Za taką wykładnią zdaje się przemawiać przepis intertemporalny art. 16 ustawy o zmianie ustawy - Kodeks postępowania administracyjnego oraz niektórych innych ustaw. Zgodnie z jego treścią do postępowań administracyjnych wszczętych a niezakończonych przed dniem wejścia niniejszej ustawy decyzją ostateczną lub postanowieniem stosuje się przepisy ustawy zmienianej $\mathrm{w}$ art. 1, w brzmieniu dotychczasowym; co oznacza a contrario, że do postępowań wszczętych po dacie wejścia w życie ustawy można i należy stosować k.p.a. w brzmieniu po nowelizacji. Jednocześnie brak jakiejkolwiek klauzuli wyłączającej moc wiążącą Kodeksu do spraw zawisłych przed organem po dacie wejścia w życie k.p.a., a wyrastających z przepisów materialnoprawnych o mocy obowiązywania sprzed daty wejścia w życie nowelizacji. Takiej roli nie wypełnia również reguła interpretacyjna lex retro non agit, która jest zasadą stosowania przepisów w warunkach konkretnej sprawy, nie zaś regułą kolizyjną w ramach obowiązującego porządku prawnego. Zasada niedziałania prawa wstecz stanowi dyrektywę postępowania organów prawodawczych, polegającą na zakazie stanowienia takich przepisów prawnych, które zawierałyby nakaz stosowania nowo ustanowionej normy prawnej do zdarzeń, które miały miejsce przed jej wejściem w życie ${ }^{28}$.

Inną regułą stosowania prawa międzyczasowego jest zasada tempus regit actum, która oznacza, że czas rządzi czynnością prawną; do czynności prawnej stosuje się przepisy obowiązujące w czasie jej dokonania. Dotyczy to w równej mierze czynności prawnych stron postępowania, jak i czynności prawnych organu. Sąd Najwyższy w uchwale z dnia 27 września 2012 r. przyjął, że zasada tempus regit actum - zgodnie z którą skutki zdarzenia prawnego ocenia się według przepisów prawa

${ }_{27}$ Por. T. Bigo, Ochrona interesu indywidualnego w projekcie kodeksu postepowania administracyjnego, "Państwo i Prawo” 1960, z. 3, s. 461.

${ }^{28}$ Por. P. Tuleja, op. cit., s. 226 i n. 
obowiązującego w chwili, gdy dane zdarzenie nastąpiło, ma charakter podstawowej reguły, która powinna wiązać w zakresie sposobu rozwiązywania problemów intertemporalnych, w tym także w zakresie stanowionego prawa intertemporalnego. Przyjmuje się nawet, że zasadę tę należy domniemywać w razie braku przepisów odnoszących się do zagadnień międzyczasowych ${ }^{29}$.

Dodatkowo zasadę lex retro non agit oraz zasadę tempus regit actum uzupełnia reguła bezpośredniego działania nowej ustawy, przy braku innych postanowień prawa intertemporalnego, której granice $\mathrm{w}$ zakresie, w jakim dotyczy ona stanów faktycznych i zdarzeń, jakie miały miejsce przed jej wejściem w życie, wyznacza zasada niedziałania prawa wstecz. Jak zauważył TK w wyroku z 31 stycznia 2001 r. ${ }^{30}$, zasada bezpośredniego działania nowej ustawy polega na tym, że od chwili wejścia w życie nowych norm prawnych należy je stosować do stosunków prawnych, zdarzeń, stanów rzeczy, które powstały lub trwają w czasie dokonywania zmiany prawa. Zasada ta umożliwia ustawodawcy dokonanie szybkiej zmiany prawa i potraktowanie stosunków prawnych danego rodzaju jednakowo według nowych norm prawnych, biorąc pod uwagę m.in. założenie, że nowe prawo odpowiada lepiej nowym warunkom jego obowiązywania niż prawo dotychczasowe ${ }^{31}$. Zasada bezpośredniego działania nowego prawa oraz założenia leżące u podstaw jej zastosowania są aktualne dla przyjęcia reguł międzyczasowego obowiązywania przepisów k.p.a. o milczącym załatwieniu sprawy.

\section{Podsumowanie}

Podnoszone zastrzeżenia co do mechanizmu objęcia regulacją k.p.a. instytucji milczącego załatwienia sprawy dają powody do twierdzenia, że nie jest to rozwiązanie dostatecznie precyzyjne i poddające się jednoznacznej wykładni. Taki stan nie napawa zatem optymizmem w kontekście praktyki stosowania prawa; może stanowić źródło rozbieżności interpretacyjnych co do zasad i trybu milczącego załatwiania spraw, a w konsekwencji wpływać destrukcyjnie na ujęty w k.p.a. model stosowania prawa przy wykorzystaniu tej instytucji. W warunkach

\footnotetext{
${ }^{29}$ Uchwała SN z 27 IX 2012 r., sygn. III CZP 45/12, BSN 2012, nr 9.

${ }^{30}$ Wyrok TK z 31 I 2001 r., sygn. P 4/99, OTK 2001, nr 1, poz. 5.

${ }^{31}$ Bliżej na ten temat M. Skonieczny, A. Okoń, Przepisy i reguty intertemporalne w prawie cywilnym. Kwestie podstawowe, „Temidium” 2013, nr 2.
} 
demokratycznego państwa prawnego niepodważalną wartością jest natomiast pewność obrotu prawnego. W związku z tym przed podjęciem czynności procesowych w sprawie zarówno organ stosujący prawo, jak i strona powinni posiadać, wyprowadzoną z przepisów prawa powszechnie obowiązującego, obiektywnie sprawdzalną znajomość nie tylko formy działania, ale i odnoszących się do niej rygorów prawnych ${ }^{32}$. Brak stabilnych i czytelnych podstaw zagraża pewności i jednolitości stosowania prawa. Dodatkowo brak precyzji w stanowionych regulacjach prawnych powoduje, że cały trud i ciężar odpowiedzialności za prawidłową interpretację przepisów spada na pracowników organów administracji publicznej. Codzienna praktyka posługiwania się formą prawną milczącego załatwienia sprawy będzie wymagała od nich dużej wiedzy i wyczucia zwłaszcza w warunkach, w których notowalibyśmy stan dywersyfikacji na instytucje, które funkcjonują w obrębie procedury sformalizowanej w k.p.a., i te pozostające poza procedurą. Ostatecznie to sąd administracyjny, w następstwie skarg wnoszonych przez strony, będzie, na drodze orzecznictwa, usuwać zachodzące w tym względzie wątpliwości, wskazując ex post zakres związania instytucji regulacją k.p.a. ${ }^{33}$

W tym stanie rzeczy zachodzi obawa, że pomimo licznych zabiegów przedstawicieli środowisk naukowych na drodze do wdrożenia odformalizowanego trybu postępowania, wypracowania rozsądnej koncepcji uproszczonej regulacji prawnej adekwatnej dla określonej kategorii spraw, Kodeks w kształcie nadanym omawianą nowelizacją nie wypełni funkcji dostatecznie uniwersalizującej model stosowania prawa przy zastosowaniu instytucji milczącego załatwienia sprawy. Taki zabieg ustawodawcy może w konsekwencji przynieść jedynie pozorne korzyści, stwarzające iluzję wzmocnionej i pełniejszej ochrony praw jednostki.

Warunkiem skuteczności ochrony w standardach wytyczonych k.p.a. jest zatem wskazanie wyraźnych podstaw dla jednolitej i klarownej

32 Sąd Najwyższy w wyroku z 18 XI 1993 r., sygn. III ARN 49/93, OSNCP 1994, nr 9, poz. 181, przyjął, że obywatel ma prawo do tego, aby jego oparte na prawie materialnym roszczenia i wnioski były rozpatrywane w ramach przewidzianej prawem procedury oraz w określonych przez prawo formach. Nie jest zgodne z zasadami konstytucyjnymi takie działanie organów administracji, w którym wnioski obywateli są załatwiane poza procedurą i $\mathrm{w}$ formach jej nieznanych. Powoduje to stan niepewności prawnej i ogranicza prawa obywateli do ochrony swych uprawnień przed organami administracji publicznej i przed sądami.

${ }^{33}$ Z już kształtującego się orzecznictwa zob.: wyrok Wojewódzkiego Sądu Administracyjnego (WSA) w Poznaniu z 17 I 2018 r., sygn. IV SA/Po 973/17, LEX nr 2453528; wyrok WSA w Gliwicach z 7 III 2018 r., sygn. II SA/G1 1133/17, LEX nr 2473500. 
formalizacji działań organu w sprawach załatwianych milcząco oraz stabilizacja wzorca podejmowanych przez organ czynności. Niewątpliwie, opowiedzenie się za koncepcją bezpośredniego stosowania Kodeksu w sprawach, dla których z przepisów prawa materialnego wynika forma "milczenia władzy" o cechach wskazanych w art. 122a $\S 2$ k.p.a., z zastrzeżeniem reguły lex specialis derogat legi generali, sprzyja uporządkowaniu i wystandaryzowaniu trybu kształtowania stosunków administracyjnoprawnych przy zastosowaniu instytucji milczącego załatwienia sprawy. Za takim stanowiskiem zasadnie przemawia wykładnia art. 1 pkt 1 k.p.a. w zw. z art. 122a § 1 k.p.a.

Należy zatem stwierdzić, że wypracowanie procesowego standardu stosowania prawa przy zastosowaniu formy milczącego załatwienia sprawy powinno być pokłosiem racjonalnej i popartej względami natury zasadniczej interpretacji rozwiązań k.p.a. w codziennym działaniu organu. Zderzenie modeli teoretycznych milczącego załatwienia sprawy z konstrukcją materialnoprawną i tą ujętą w ustawie procesowej k.p.a. pozwoli dopiero $\mathrm{w}$ konfrontacji z praktyką stosowania prawa zweryfikować znaczenie zrealizowanej inicjatywy ustawodawczej dla kształtowania podstaw efektywnej ochrony prawnej jednostki. Poddanie reżimowi k.p.a. instytucji milczącego załatwienia sprawy stanowi bowiem istotny krok na drodze afirmacji trybów uproszczonych załatwienia spraw administracyjnych i roli w tym zakresie Kodeksu. Dokonana zmiana, jakościowo odmienna od tendencji panujących przy poprzednich dużych nowelizacjach, stanowi wyznacznik pozytywnego trendu zmierzającego do otwarcia kodyfikacji na nowe formy działania administracji, uwzględniające element efektywności postępowania - postrzeganej przez pryzmat szybkości i użyteczności procedury, przy jednoczesnym zachowaniu gwarancji skutecznej ochrony prawnej jednostki.

\section{APPLICATION OF THE PROVISIONS OF THE CODE OF ADMINISTRATIVE PROCEDURE ON SILENT SETTLEMENT OF A MATTER}

\section{Sum mary}

The subject of the considerations is the issue of the scope of the Code of Administrative Procedure in matters for which an institution of silent settlement is provided in separate provisions. The matter outlined above is the source of controversy which arises from the mechanism of anchoring to the framework of the Code of Administrative Procedure the institution of silent settlement under the act by the 
Act of 7 April 2017 amending the Act - Code of Administrative Procedure and certain other acts. It should be emphasised that the idea underlying the inclusion of the Code of this legal institution in the subject of regulation was to ensure proper effectiveness of the application of law by administrative means, to significantly reduce the social costs of launching the procedure and to deformalise as much as possible the activities undertaken in the official mode. The source of the concept was also the need to organise and comprehensively regulate the matter of individual administrative matters settled in a silent manner, which until now, functioned in substantive administrative law in a dispersed manner, with a diversified specificity of legal solutions. The measure of such a codification process was to be the formation of a uniform and clear procedural regime in the field of administrative law relations, expressed in the forms of silent settlement of a matter, on the one hand based on the formula of limiting formal requirements to the minimum necessary, and on the other hand corresponding to the features of the jurisdictional process with guarantees of protection of individual rights and the rule of law. However, the question arises whether such boundary conditions are fulfilled by the model of fusion with the Code of Administrative Procedure of the institution of silent settlement of the matter. For the practice of applying the law with the use of the institution, rooted already in the acts of the substantive law of the institution, there is a special significance in terms of reference to the procedural constructions of Chapter $8 \mathrm{a}$ of the Administrative Procedure Code. The issue of fundamental importance for defining the role of the act in the field of connecting the institution of silent settlement of a matter with the Code is not only the objective separation of the sphere of influence of unified formal and legal solutions of this act, but also defining the manner of merging procedural issues of the institution with the Code.

Keywords: The Code - silent handling of a matter - proceeding 